\title{
Implementation of Lean Tools in Apparel Industry to Improve Productivity and Quality
}

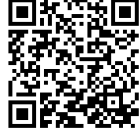

\author{
Mothilal B and Prakash C* \\ Department of Fashion Technology, Sona College of Technology, India
}

Submission: April 19, 2018; Published: July 02, 2018

*Corresponding author: Prakash C, Department of Fashion Technology, Sona College of Technology, India, Tel No: +91-427-4099830; Fax: +91-4274099888; Email: dearcprakash@gmail.com

\section{Abstract}

The rapid change in apparel styles, deviation of order quantities and increasing quality levels at the lowest possible cut-rate, demand the apparel manufacturing industry to be focused on more effective and efficient manufacturing processes for survival in an immensely competitive market. To increase the productivity of the apparel industries we need to reduce the wastage of the manufacturing and time to manufacture the product. Lean is the tool to reduce the wastage in all process of apparel manufacturing, reducing cost and value added to the product. This paper proposes the lean tool for the apparel industry to reduce the overall wastage of the industries.

Keywords: Apparel industry; Eco-efficiency; Industrial wastes; Lean tools

Abbreviations: FMEA: Failure Mode and Effect Analysis; SFPS: Single Failure Points; TPM: Total Productive Maintenance; OEE: Overall Equipment Effectiveness; PDCA: Plan-Do-Check-Act or Plan-Do-Check-Adjust; PDSA: Plan-Do-Study-Act

\section{Introduction}

Tapping D [1] observed thatlean strategy is to eliminate wastes from the process. Any excess in equipment's, materials, parts, and working period beyond the requirement is generally referred as waste. Taj S [2] observed that waste ("muda" in Japanese) has seven types: waste from overproduction than required quantity, waste of waiting time for subsequent operations, transportation wastage, inventory of goods, processing waste, the waste of motion, and waste from product defects. The apparel industry exists more number of wastes so that, there must implement the lean tools. This industry comprises majorly three departments cutting department, sewing department, ironing and packing department. Karthikadevi M [3]suggested that with the help of lean manufacturing tool the apparel industry can provide a high-quality product to their customer by satisfying their requirements.

This paper presents a review of literature on lean manufacturing tools for the apparel industries suggested by previous researchers which will improve the productivity as well as quality in apparel/garment industries.

\section{Lean tools}

Lean 'tools' assist in the identification and steady elimination of waste (muda), the improvement of quality, and production time and cost reduction. Figure 1 shows the common lean tools[4].

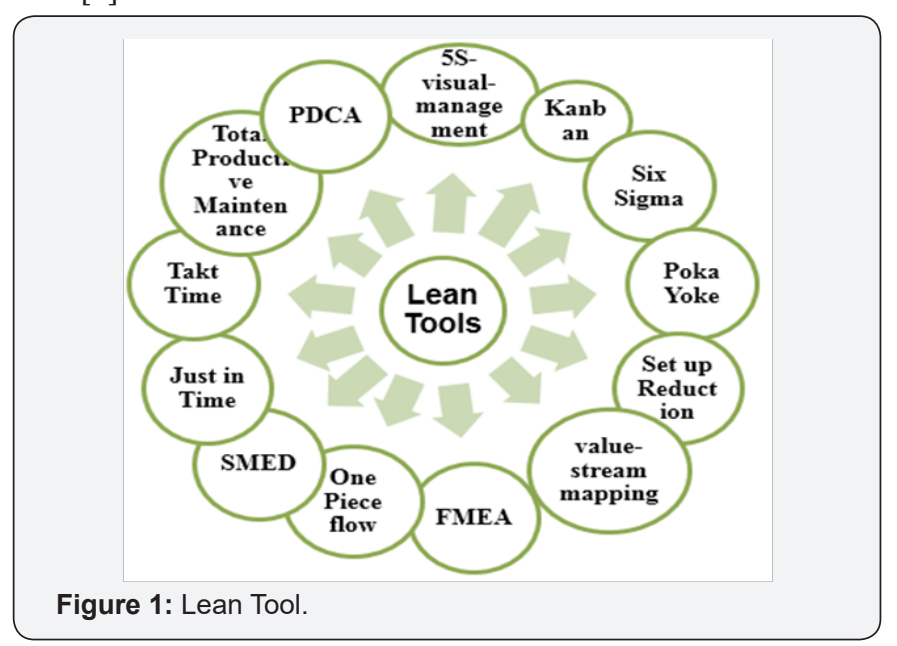




\section{S-visual-management}

$5 \mathrm{~S}$ visual management is one of the lean tools which make an improvement in process as shown in Figure 2 which is originated by the Japanese to create a workplace that supports companywide integration of workplace organization, standardization, visual control, visual display, and visual metrics.

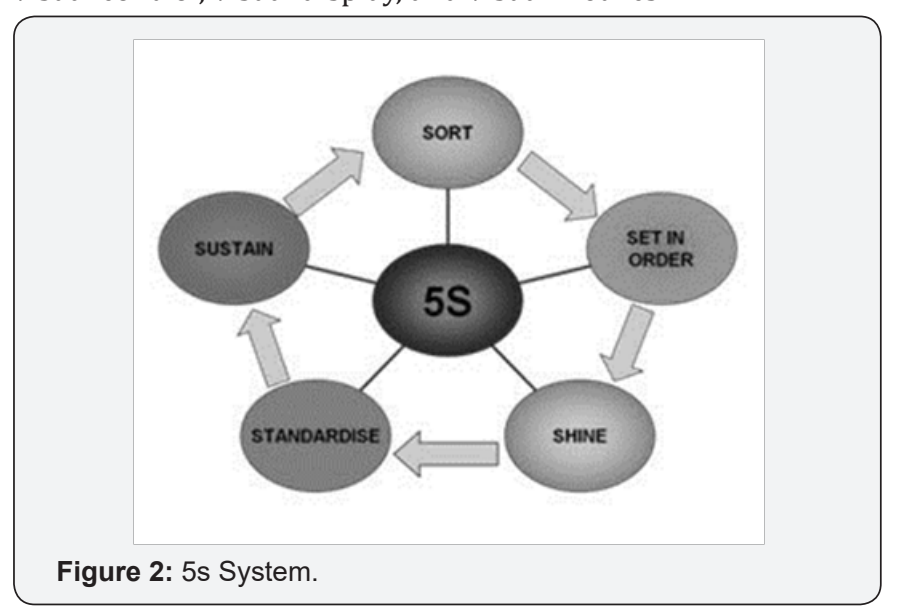

\section{The five principles of $5 S$ system}

Seiri (sort) means to separate needed tools, parts, and instructions from the unneeded. The goal is to keep only what is required and eliminate everything else. Seiton (set in order) means to neatly arrange and identify parts, processes, and tools for ease of use. Seiso (shine) means to clean, shine, and inspect the workplace by eliminating contamination. Seiketsu (standardize) means to require as the norm sort, set in order, and shine activities daily to keep the workplace in perfect condition and also to make use of visual control systems to maintain compliance with the established standards. Shitsuke (sustain) means to maintain the $5 \mathrm{~S}$ gains by training and encouraging workers to form the habit of always following the first four S's.

Benefits of 5S: Reduce workflow problems, increases product quality and productivity, as well as improve communication. Improves workplace safety by eliminating hazards and establishing compliance to work standards. Align employee efforts with goals and strategies for eliminating waste. The improve appearance of the facility and expectation of compliance to maintain that condition. Established standards for operating equipment and conducting processes. Reduce training time for new employees. Improve quality from preventing defects and errors from occurring. Reduce changeover time, tool search time, lead time, cycle time \& materials handling. Increase floor space. Improve morale and pride in the workplace. Decrease work flow distance. Reduce equipment breakdowns yield better equipment utilization[5].

\section{Kanban}

Kanban is a Japanese word that means a card or signal. This is an important tool for improving production from a push to a pull system. As shown in Figure 3 at the core of pull production, upstream operations signal the prior operation to deliver what is needed, in the quantity needed, and when needed. A kanban system can be manual or automated.A pull system can use various signal methods to trigger replenishment such as physical, $\mathrm{min} / \mathrm{max}$ levels, and cards, electronic, interplant, and single enterprise.

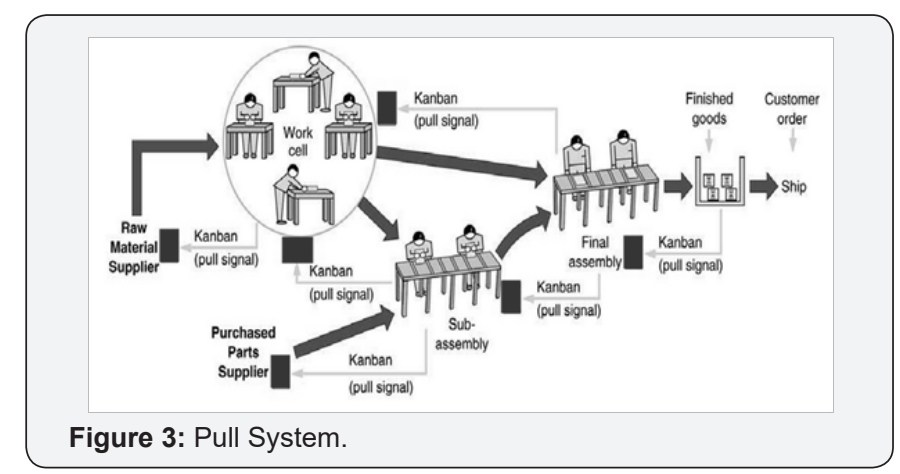

Benefits of Kanban: Integrate all processes into one another and connects the value stream to your customer demand. Improve flexibility to respond to customer demand. Simplify the procurement process. Uncover hidden waste in processes. Empower employees to produce based on customer demand. Improve production scheduling. Eliminate unnecessary paperwork. Eliminate overproduction. Reduce inventory of finished goods, raw materials, and subassemblies.

\section{Six Sigma}

Six Sigma means a measure of quality that strives for near perfection. Six Sigma is a disciplined, data-driven approach and methodology for eliminating defects (driving toward six standard deviations between the mean and the nearest specification limit) in any process from manufacturing to transactional and from product to service (Figure4).

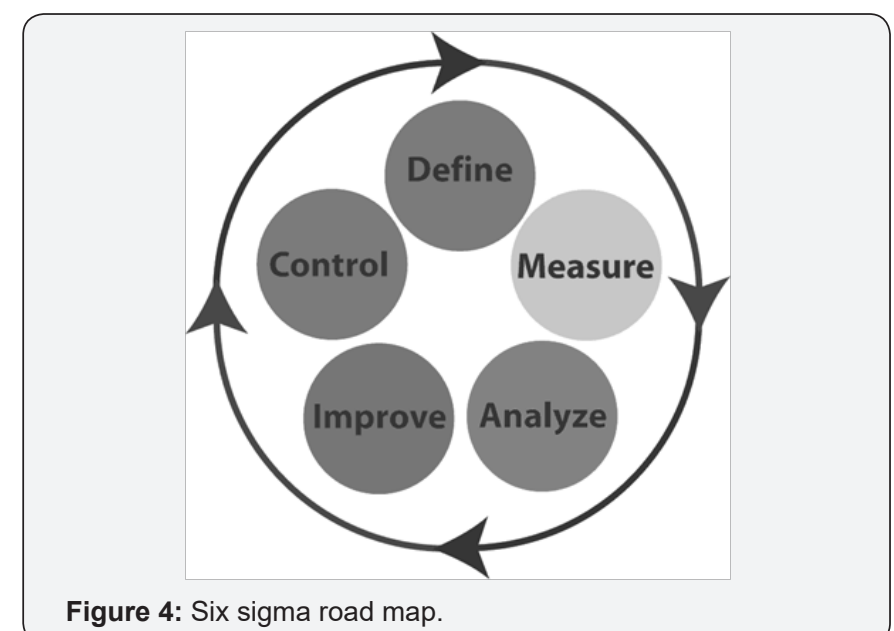

Figure 4: Six sigma road map.

Benefits of six sigma: Bottom line cost savings (5\%-20\% of turnover per annum). Improved quality of product or service as perceived by the customer (internal and external customers). Reduction in process cycle times. Development of staff skills. 
Common language throughout the organization. World class standard. Ability to use a wide range of tools and techniques.

\section{Poka Yoke}

Poka Yoke is a Japanese term which was coined by a Japanese Engineer named Shingeo Shingo. This was originally called as Baka Yoke during 1961 which means "foolproofing". This was not liked by employees because of its negative connotation. Pokayoke is the conviction that it is not acceptable to produce even a small number of defective goods (Figure5). To become a worldclass competitor, a company must adapt not only a philosophy, but a practice of producing zero defects. Poka-yoke methods are simple concepts for achieving this goal.

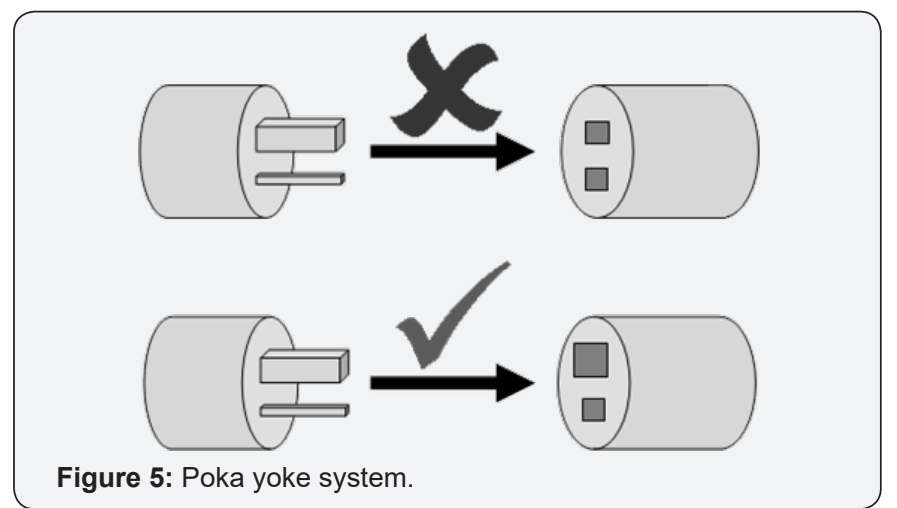

Benefits of Poka yoke: Reduction in waste and associated machining as nonconforming material is identified at each stage rather than an inspection stage between several pairs of stages. Reduction of waste in the system leads to a reduction in inventory holdings. Improvements in customer satisfaction levels because the better-quality product is delivered to them. Improvement in employees' relationships as it encourages more involvement of operators and team members[6].

\section{One-Piece-Flow}

One-piece flow means production of the product moves from one stage to the next stage one piece at a time as shown in the Figure 6. Compare that to lot production where several units are made at a given stage and then all are moved to the next stage at the same time. Most operational excellence practitioners promote one piece movement.

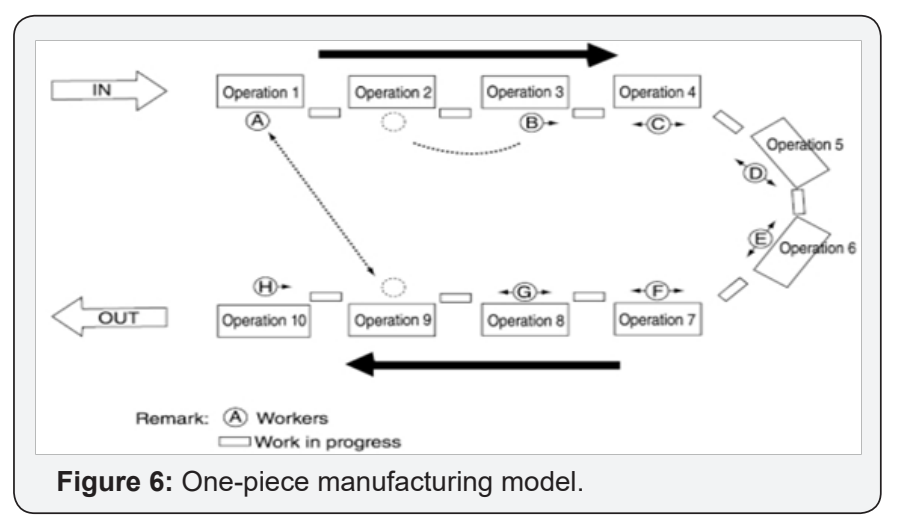

Benefits of one piece flow: Reduce throughput time and increases velocity for customer orders from order receipt through production and shipment. Improve value-added ratio through elimination of non-value-added activities which reduces operating costs. Allow the company higher degrees of flexibility to accommodate changes in customer demand. Save space in the factory. Promote continuous improvement as problems are exposed. Reduce transportation, waiting, overproduction, processing, inventory, and motion waste that occurs with batch processing. Lower the risks of product damage, deterioration, and obsolescence. Simplify scheduling. Support high-variety production. Reduce cycle time through increased production velocity. Support quality production.

\section{Set up Reduction}

Setup time is defined as the time to change from the last item of the previous order to the first good item on the next order. Setup includes preparation, replacement, location and adjustment activities (Figure 7). When analyzing setup activities, note whether the activity is internal or external. Internal setup activities require an inactive (shut down) process, meaning that no orders can run while the setup activity is taking place. External setup activities may be done while the process is operational. They are offline activities.

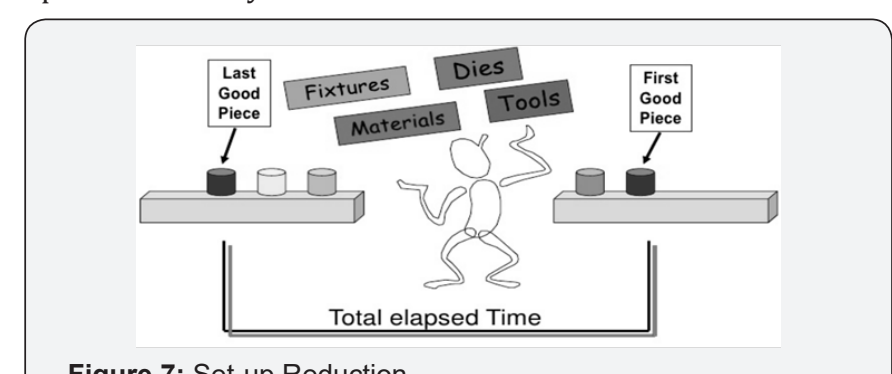

Figure 7: Set-up Reduction.

Benefits of setup reduction: Shorter lead time, increased capacity \& flexibility. Capital equipment purchases avoided or delayed. Better quality/more-consistent processes \& better workforce utilization. Lower manufacturing costs and improved cash flow. Less process variability \& inventory.

\section{Value-stream-mapping}

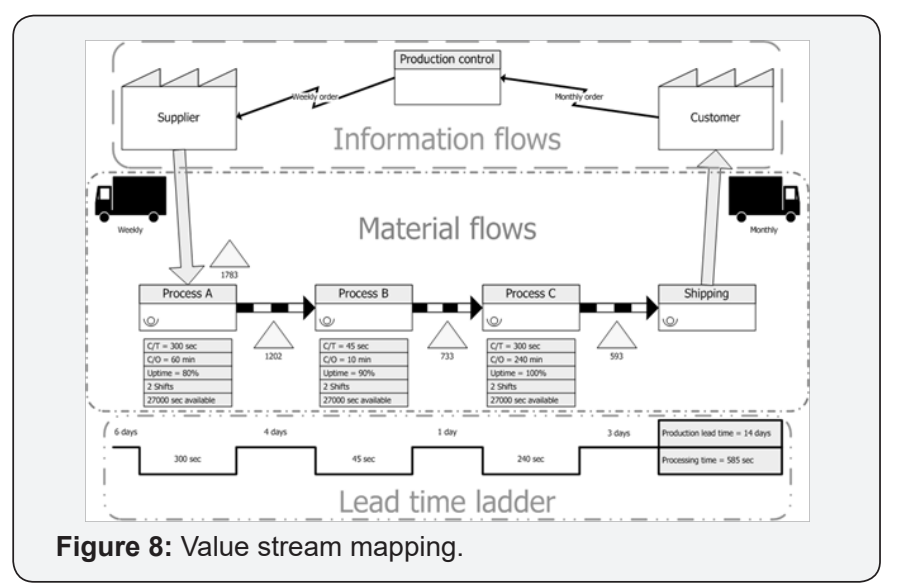


Value stream mapping is a visual diagram that represents the activities to produce a product or service through the design, source, make, and deliver functions (Figure 8). Creating a value stream is the first step required in any lean improvement[7].

Benefits of Value stream mapping: Create a graphic visualization of the entire material and information flow for the current-state value stream. Show linkages and connections between information flow and material flow. Identify nonvalue-added steps, lead time, distances travelled, and amount of inventory for a process \& sources of waste in the value stream. Provide a common language for talking about the processes. Make decisions about the apparent flow. Form the basis of an implementation plan to identify and eliminate wastes. Provide a common language for discussing the future-state value stream and identifying gaps between the current state and future state.

\section{FMEA}

Failure Mode and Effect Analysis (FMEA) model to prioritize potential defects based on their severity, expected frequency, and likelihood of detection. The Failure Mode and Effect Analysis highlight weaknesses in the current design or process. This tool prioritizes and organizes continuous improvement efforts on areas which offer the greatest return. From the Table 1 it has shown that the failure mode number two has an RPN of 144. This issue has the highest priority for process improvement.

Table 1: Example of Failure Mode \& Effects Analysis.

\begin{tabular}{|c|c|c|c|c|}
\hline $\begin{array}{c}\text { Failure } \\
\text { Mode }\end{array}$ & $\begin{array}{c}\text { A) } \\
\text { Severity }\end{array}$ & $\begin{array}{c}\text { B) } \\
\text { Probability } \\
\text { of } \\
\text { Occurrence }\end{array}$ & $\begin{array}{c}\text { C) } \\
\text { Probability } \\
\text { of Detection }\end{array}$ & $\begin{array}{c}\text { Risk } \\
\text { Preference } \\
\text { Number } \\
\text { (RPN) } \\
\mathbf{A}^{*} \mathbf{B}^{* \mathbf{C}}\end{array}$ \\
\hline $\begin{array}{c}\text { 1) Selecting } \\
\text { wrong colour } \\
\text { Button }\end{array}$ & 5 & 4 & 3 & 60 \\
\hline $\begin{array}{c}\text { 2) Size of } \\
\text { buttons is } \\
\text { uneven }\end{array}$ & 9 & 2 & 8 & 144 \\
\hline $\begin{array}{c}\text { 3) Trim } \\
\text { cover clip } \\
\text { Misaligned }\end{array}$ & 2 & 3 & 4 & 24 \\
\hline
\end{tabular}

Note: Rate from 1-10 where 10=Lowest probability

Benefits of FMEA: It provides a documented method for selecting a design with a high probability of successful operation and safety. A documented uniform method of assessing potential failure mechanisms, failure modes and their impact on system operation, resulting in a list of failure modes ranked according to the seriousness of their system impact and likelihood of occurrence. Early identification of Single Failure Points (SFPS) and system interface problems, which may be critical to mission success and/or safety. They also provide a method of verifying that switching between redundant elements is not jeopardized by postulated single failures. An effective method for evaluating the effect of proposed changes to the design and/or operational procedures on mission success and safety. A basis for in-flight troubleshooting procedures and for locating performance monitoring and fault-detection devices. Criteria for early planning of tests.

\section{SMED}

SMED stands for Single Minute Exchange of Dies and was devised by Shigeo Shingo. It is a key component of rapid changeover (Figure 9). "SMED=Exchange dies in less than 10 minutes". Changeover time is the actual clock time, not labour time or work content. It is used to control and decrease downtime due to changeovers. SMED supports the concept of continuous improvement through the removal of waste. SMED will make the job more structured, repeatable.

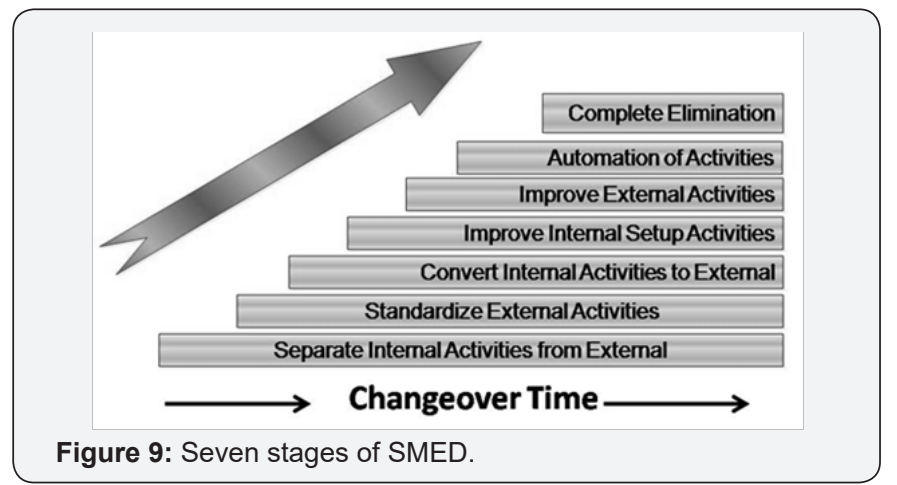

Benefit of SMED: Reduced setup time and Work in progress. Higher efficiencies, increased capacity, flexibility \& safety.Lower batch sizes which eliminate the waiting time. Achieve stockless production.

\section{Just in Time}

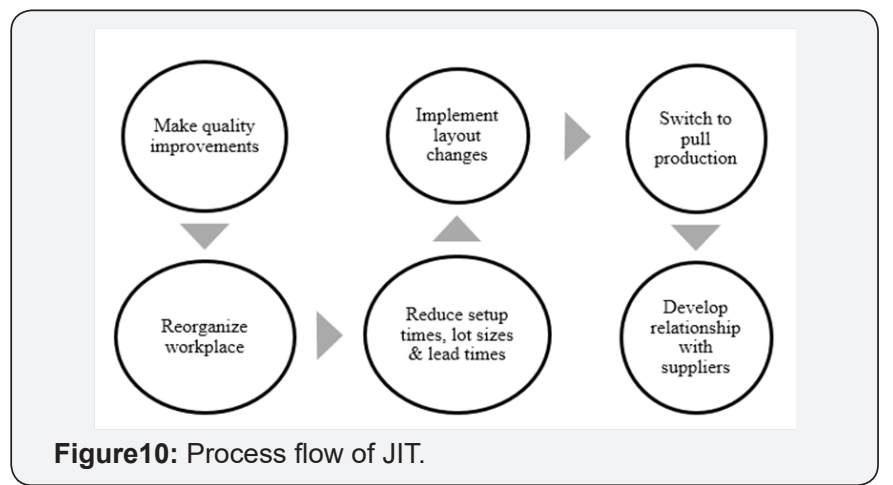

JIT philosophy means getting the right quantity of goods at the right place and the right time. JIT exceeds the concept of inventory reduction. It is an all-encompassing philosophy geared to eliminate waste, anything that does not add value. The process flow of JIT shown in Figure 10. JIT is achieved by focusing the element like Inventory reduction - exposes problems, Kanbans\& pull production systems, Small lots \& quick setups, Uniform plant loading, Flexible resources, Efficient facility layouts.

\section{Implement the sequence of seven steps}

1. Make quality improvements

2. Reorganize workplace 
3. Reduce setup times, lot sizes \& lead times

4. Implement layout changes

5. Switch to pull production

6. Develop relationship with suppliers

Benefit of JIT: Reduction in inventories \& space requirements.Improved quality \& flexibility.Shorter lead times. Lower production costs.Increased productivity \& machine utilization.

\section{Takt Time}

Takt Time is defined as «The rate at which the end product or service must be produced and delivered in order to satisfy a definite customer demand within a given period of time. It is calculated:

$$
\text { Takt Time }=\frac{\text { Available Work Time in Period }}{\text { Average Demand in Period }}
$$

For example, if a process runs 24 hours a day and the market demand is 240 entities per day then:

$$
\text { Takt Time }=\frac{(24 * 60) \text { minutes }}{240 \text { units }}=6 \text { minutes } / \text { unit }
$$

Benefits of Takt Time: Production Stability which helps for Work cell Design. Receiving immediate feedback on performance.

\section{Total Productive Maintenance}

Total Productive Maintenance (TPM) emphasizes total participation of employees to achieve maintenance free operations through prevention of six major equipment losses such as equipment failures, set-up \& adjustment losses,idling \& minor stoppages, reduced speed, process defect losses, yield lossesand through development of eight plus one major TPM pillars (Figure 11).Measuring and monitoring overall performance using Overall Equipment Effectiveness (OEE).

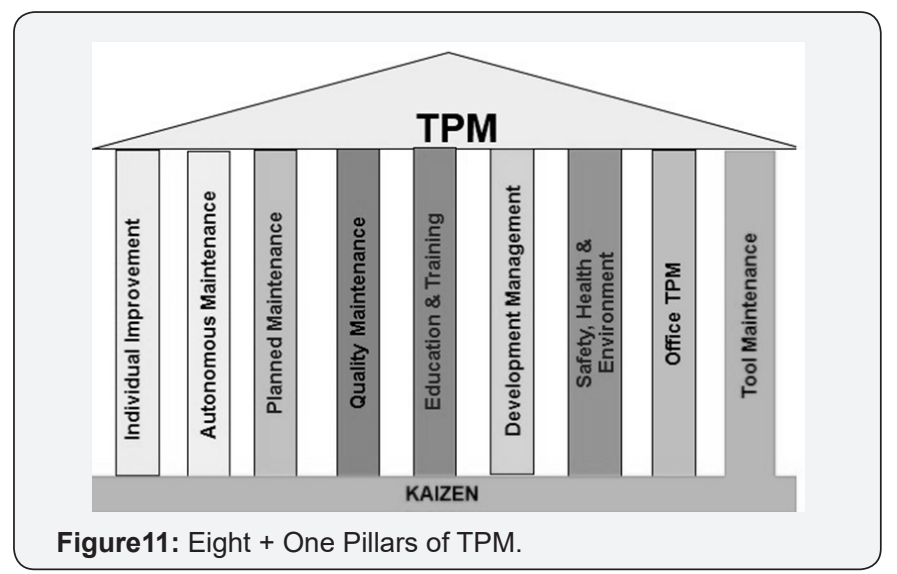

\section{Calculation of OEE}

$\mathrm{OEE}=$ Availability $\mathrm{x}$ Performance rate $\mathrm{x}$ Quality rate

Availability $=$ (Loading time - Set-up time - Down time) x100/Loading time

Performance rate $=($ Average cycle time $\mathrm{x}$ Number of good units made) $\times 100 /$ Operating time
Quality rate $=($ Total units produced - Rejected units $) \mathrm{x} 100 /$ Total units produced

Benefits of TPM: Zero Unplanned Downtime,Defects, Speed Losses and Accidents. Productivity Improvement and cost Reduction. Employee Ownership \& confidence. Improved working environment and increased Plant Reliability with customer Satisfaction

\section{PDCA}

PDCA (plan-do-check-act or plan-do-check-adjust) is an iterative four-step management method used in apparel manufacturing for the control and continuous improvement of processes and products. It is also known as the deming circle/ cycle/wheel, Shewhart cycle, control circle/cycle, or plan-dostudy-act (PDSA) (Figure 12). Another version of this PDCA cycle is OPDCA. The added «0» stands for observation or as some versions say, «Grasp the current condition.»

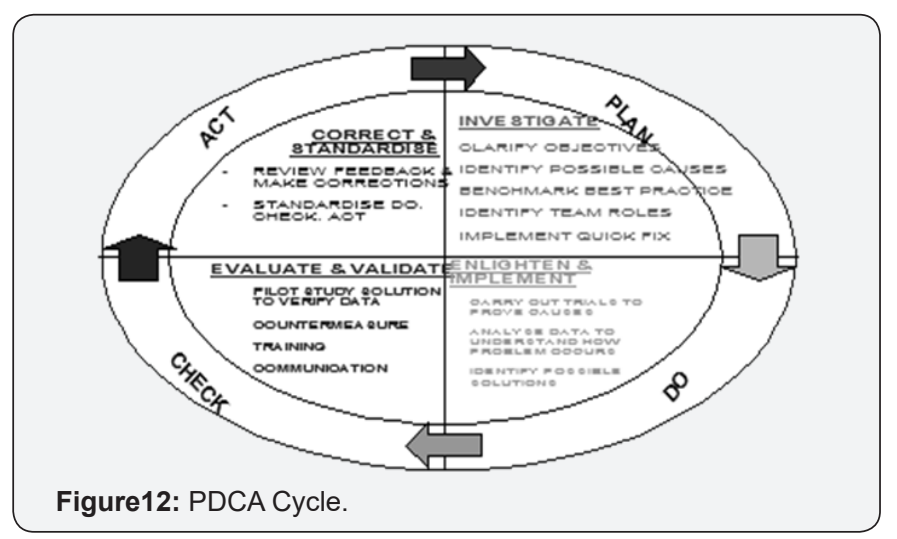

Benefits of PDCA: Daily routine management-for the individual and/or the team. Problem-solving process. Project management and continuous development. Vendor and human resources development. New product development as well can see the process trials.

\section{Conclusion}

Due to increased customer expectations and severe global competition, the Indian apparel manufacturer tries to eliminate the waste, increase productivity at lower cost and to produce with the best product and service quality. Under these considerations, the authors have reviewed the lean manufacturing tools to improve the process environment by elimination of waste with a reasonable investment. The lean tools are well suited for reducing and managing the apparel manufacturing waste.In this paper, the effectiveness of lean tools is substantiated in systematic manner with the help of various systems, such as Value Stream Maps, SMED, JIT \& etc...we hope that this paper contains its worth for practitioners in the apparel manufacturing.

\section{References}

1. Tapping D (2006) The Lean Pocket Guide XL-Tools for the Elimination of Waste. Kindle Edition, Kindle Book. 


\section{Current Trends in Fashion Technology \& Textile Engineering}

2. Taj S (2008) Lean manufacturing performance in China: assessment of 65 manufacturing plants. Journal of Manufacturing Technology Management 19(2): 217-234

3. Karthikadevi M (2014) Lean Based Manufacturing to Increase the Productivity, Quality and reduce waste of Textile Industries. International Journal of Industrial Engineering (SSRG-IJIE) 1(1): 2332.

4. Islam M, Khan AM, Islam M (2013) Application of lean manufacturing to higher productivity in the apparel industry in Bangladesh. International Journal of Scientific \& Engineering Research 4(2): 1-10.
5. Mardhamuthu R, Krishnaswamy R, Pillai DM (2011) The development and implementation of lean manufacturing techniques in Indian garment industry. Jordan Journal of Mechanical and Industrial Engineering 5(6): 527-532.

6. Miralles C, Holt R, Juan A, Marin-Garcia, Canos-Daros L (2011) Universal design of workplace through the use of Poka-Yokes: Case study and implications. Journal of Industrial Engineering and Management 4(3): 436-452.

7. Silva SKPN (2012) Applicability of Value Stream Mapping (VSM) in the apparel industry in Sri Lanka. International Journal of Lean Thinking 3(1): 36-41.

\section{Your next submission with Juniper Publishers} will reach you the below assets

- Quality Editorial service

- Swift Peer Review

- Reprints availability

- E-prints Service

- Manuscript Podcast for convenient understanding

- Global attainment for your research

- Manuscript accessibility in different formats

( Pdf, E-pub, Full Text, Audio)

- Unceasing customer service

Track the below URL for one-step submission https://juniperpublishers.com/online-submission.php 